\title{
Stainless Steel lons Stimulate Increased Thrombospondin-1-Dependent TGF-Beta Activation by Vascular Smooth Muscle Cells: Implications for In-Stent Restenosis
}

\author{
Manuel A. Pallero ${ }^{\mathrm{a}}$ Melissa Talbert Roden ${ }^{\mathrm{a}}$ Yiu-Fai Chen ${ }^{\mathrm{b}}$ Peter G. Anderson ${ }^{\mathrm{a}}$ \\ Jack Lemons ${ }^{c}$ Brigitta C. Brott ${ }^{b}$ Joanne E. Murphy-Ullrich ${ }^{a}$ \\ Departments of a Pathology, ${ }^{b}$ Medicine and ${ }^{c}$ Prosthodontics, University of Alabama at Birmingham, \\ Birmingham, Ala., USA
}

\section{Key Words}

Restenosis · Smooth muscle cells · TGF- $\beta$ •

Thrombospondin- $1 \cdot$ Stent corrosion $\cdot$ Hydrogen peroxide

\begin{abstract}
Background/Aims: Despite advances in stent design, instent restenosis (ISR) remains a significant clinical problem. All implant metals exhibit corrosion, which results in release of metal ions. Stainless steel (SS), a metal alloy widely used in stents, releases ions to the vessel wall and induces reactive oxygen species, inflammation and fibroproliferative responses. The molecular mechanisms are unknown. TGF- $\beta$ is known to be involved in the fibroproliferative responses of vascular smooth muscle cells (VSMCs) in restenosis, and TGF$\beta$ antagonists attenuate ISR. We hypothesized that SS ions induce the latent TGF- $\beta$ activator, thrombospondin-1 (TSP1), through altered oxidative signaling to stimulate increased TGF- $\beta$ activation and VSMC phenotype change. Methods: VSMCs were treated with SS metal ion cocktails, and morphology, TSP1, extracellular matrix production, desmin and TGF- $\beta$ activity were assessed by immunoblotting. Results: SS ions stimulate the synthetic phenotype, increased TGF- $\beta$ activity, TSP1, increased extracellular matrix and downregulation of desmin in VSMCs. Furthermore, SS ions increase hy-
\end{abstract}

drogen peroxide and decrease cGMP-dependent protein kinase (PKG) signaling, a known repressor of TSP1 transcription. Catalase blocks SS ion attenuation of PKG signaling and increased TSP1 expression. Conclusions: These data suggest that ions from stent alloy corrosion contribute to ISR through stimulation of TSP1-dependent TGF- $\beta$ activation.

Copyright $\odot 2009$ S. Karger AG, Basel

\section{Introduction}

In-stent restenosis (ISR) is a fibroproliferative response of the vessel wall to injury, characterized by initial inflammatory responses, VSMC proliferation, late loss of cells and accumulation of extracellular matrix in the neointimal layer, resulting in loss of luminal area [1]. ISR remains a significant clinical problem despite advances in stent design and the use of drug-eluting stents [2]. Metal alloys commonly used for stents are subject to stress/ strain fracture related to crevice and pitting corrosion due to both mechanical and environmental factors. Reports of stent fractures are increased, particularly after drug-eluting stent deployment [3-5]. Furthermore, the polymer and diamond-like carbon coatings applied to stent surfaces are known to crack and degrade with time,

\section{KARGER}

() 2009 S. Karger AG, Base

Fax +41613061234

E-Mail karger@karger.ch

www.karger.com 
particularly when subject to mechanical strain $[6,7]$. This degradative process releases metallic ions that localize to tissue surrounding implants [8]. This process is significant, because increased stent corrosion is associated with increased rates of neointimal proliferation $[9,10]$. Yet, the mechanisms underlying this response are not understood. High concentrations of metal ions are toxic to VSMCs in vitro and sublethal concentrations stimulate both inflammatory and fibrotic reactions $[11,12]$. Stainless steel (SS) is particularly conducive to stimulation of fibrous tissue formation and inflammatory (allergic) responses, which are associated with increased rates of restenosis [11]. Stent implantation, SS surfaces and iron and manganese, components of SS, are all known to increase reactive oxygen species (ROS) [13-15]. Despite the fact that restenosis involves both inflammatory and fibroproliferative responses, there have been no studies addressing the role of metal ions on the behavior of vascular smooth muscle cells (VSMCs) in ISR.

TGF- $\beta$ is a pluripotent growth factor which drives fibroproliferative responses critical to restenosis through the canonical Smad signaling pathway as well as other associated pathways $[16,17]$. TGF- $\beta$ action is highly regulated: latent TGF- $\beta$ must be converted to its active form in order to elicit biological activity. Thrombospondin-1 (TSP1) is an activator of latent TGF- $\beta$ and an extracellular matrix protein that is induced by growth factors and injury [18]. TSP1 binding to the latent complex alters the conformation of the complex which renders TGF- $\beta$ biologically active [19]. We have mapped the critical sites of interaction between TSP1 and the latent TGF- $\beta$ complex [20] and we have developed a peptide (LSKL) which functions as a competitive antagonist of TSP1 binding to and activation of the latent complex. The LSKL peptide is an inhibitor of TSP1-dependent TGF- $\beta$ activation both in vitro and in several different rodent disease models in vivo, including diabetes and hypertension [21, 22]. TSP1 is upregulated following stent deployment and evidence suggests a role for TSP1 in restenosis [23, 24]. TSP1 expression is increased by ROS, partly through attenuation of cGMP-dependent protein kinase (PKG) transcriptional repression [25]. The role of TSP1-dependent TGF- $\beta$ activation in ISR is not known.

Phenotypic switching of VSMCs is typical of restenotic remodeling in ISR $[1,26]$. These synthetic VSMCs acquire myofibroblastic-like characteristics with loss of desmin expression and produce increased extracellular matrix components, including TSP1 and ED-A fibronectin (ED-A FN) [27-30]. Interestingly, $\alpha$-smooth muscle actin (SMA)-positive cells predominate in the neointima, suggesting a role for myofibroblast-like cells of either smooth muscle or other origin in restenotic remodeling $[1,26]$. Because TGF- $\beta$ stimulates myofibroblast differentiation and SMC differentiation of mesenchymal progenitors, TGF- $\beta$ is likely important for these phenotypic changes in ISR [31].

Based on the known role of TGF- $\beta$ in ISR and the observations of stent metal ion release to the vascular wall, we hypothesized that ions from SS stimulate increased TGF- $\beta$ activity in VSMCS through upregulation of TSP1. The increased TGF- $\beta$ activity potentially contributes to VSMC phenotype switching to induce ISR through fibroproliferative responses. We now report that SS ions stimulate increased TSP1 expression which results in enhanced TGF- $\beta$ activation, extracellular matrix production and loss of desmin expression. Furthermore, we show that SS ions stimulate hydrogen peroxide release and attenuate PKG activity through a catalase-dependent mechanism to upregulate TSP1 expression. These studies identify a novel mechanism by which stent corrosion contributes to ISR.

\section{Materials and Methods}

\section{Materials}

TSP1 Purification. TSP1 stripped of associated TGF- $\beta$ was purified from thrombin-stimulated, pooled, outdated human platelet packs purchased from the American Red Cross [32].

Chemicals. Catalase (C9322) and 8-(chlorophenylthio)guanosine 3':5'-cyclic monosphosphate sodium salt (8pCPT-cGMP) (C5438) were purchased from Sigma-Aldrich (St. Louis, Mo., USA). Recombinant human TGF- $\beta 1$ (240B) was purchased from R\&D Systems (Minneapolis, Minn., USA).

Peptides. LSKL, SLLK, GGWSHW were synthesized and purified to $>95 \%$ purity (Anaspec Inc., San Jose, Calif., USA). LSKL and GGWSHW are peptides from the latency-associated peptide region of latent TGF- $\beta$ and from the type 1 repeats of TSP1, respectively, which act as competitive antagonists of TSP1-dependent TGF- $\beta$ activation, and SLLK is an inactive control peptide [19].

Antibodies. The following antibodies were purchased: mouse anti ED-A FN, clone IST-9 and rabbit anti- type I collagen (ab292) (ABCAM); nonimmune mouse IgG, mouse anti- $\alpha$-SMA, clone 1A4, mouse anti-vimentin (V6389) (Sigma-Aldrich); mouse antidesmin, clone RD301, rabbit anti-PKG (PA128083), mouse anticalponin (MA1-37219) (Affinity BioReagents); rabbit anti-phospho Smad 2 (ser465/467) (3101) and rabbit anti-phospho VASP (ser239) (3114) (Cell Signaling Technology); mouse anti-Smad 2/3 (610842) (BD Transduction Laboratories); rabbit anti- $\beta$-tubulin, clone H235 (SC9104) (Santa Cruz Biotechnology); rat anti-F4/80 Antigen, cloneA3-1 (MCA497GA) (AbD Serotec); mouse antiCD68 (MAB1435), mouse anti-CD11b (CBL1512Z) (Chemicon International). Secondary horseradish peroxidase (HRP)-tagged antibodies were purchased from Jackson Immunoresearch Labs. 

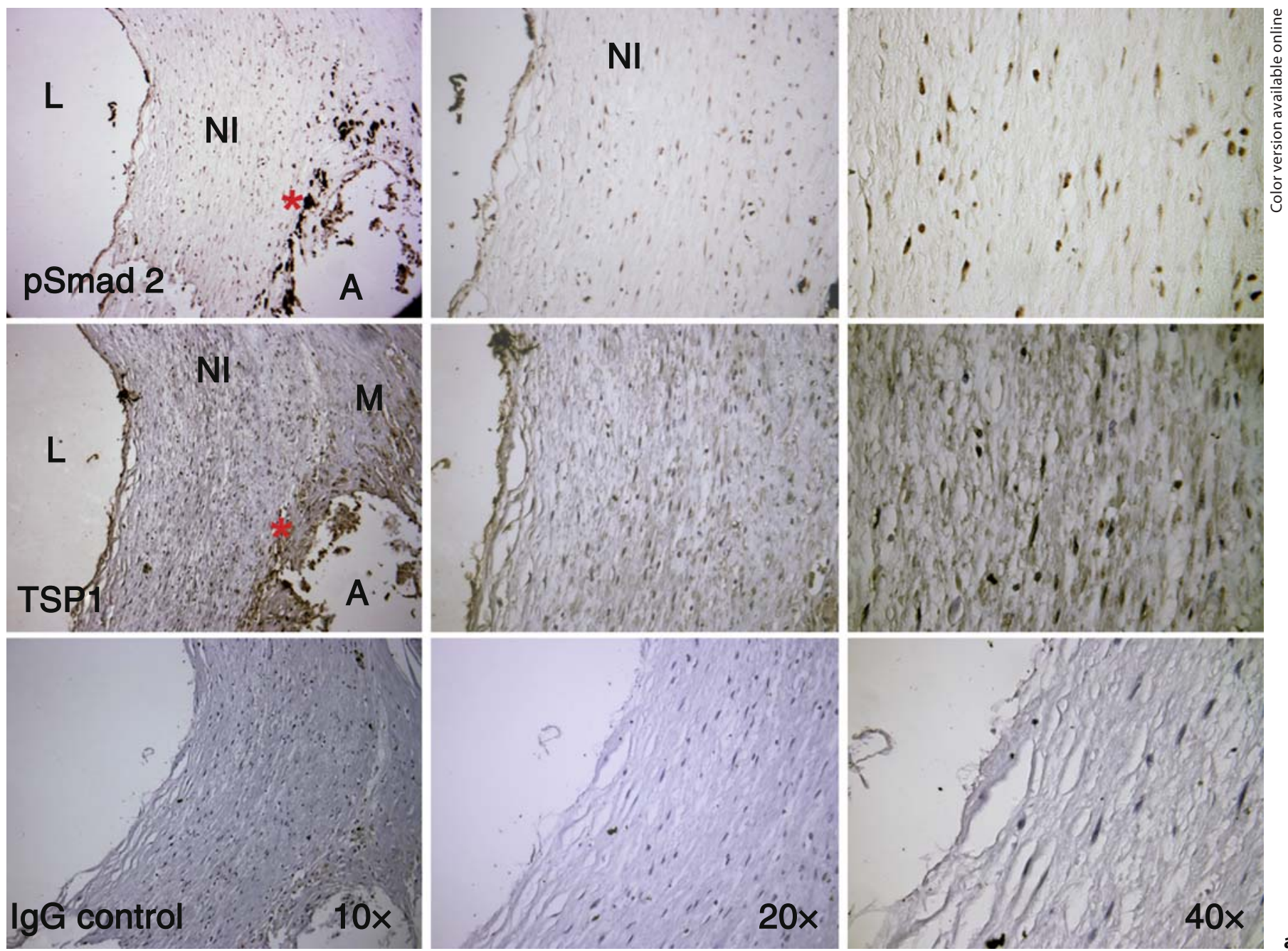

Fig. 1. TSP1 and active TGF- $\beta$ (pSmad 2$)$ are expressed in arteries with ISR. a Left circumflex artery showing restenotic remodeling from a patient who received a SS drug-eluting stent (Taxus) at least 1 year prior to harvesting of vessels with ISR at the time of cardiac transplant. There is staining for both TSP1 and nuclear

pSmad 2 in the endothelium and in the restenotic neointimal VSMCs (NI). There are also macrophages $\left(^{*}\right)$ and VSMCs in a region of atheroma (A) adjacent to the restenotic remodeling that also stain for $\mathrm{pSmad} 2$ and TSP1, respectively. $\mathrm{L}=$ Lumen; $\mathrm{M}=$ media.

Goat anti-rabbit IgG-Biotin (BA1000), horse anti-mouse IgG-Biotin (BA2001) and goat anti-rat IgG-Biotin (BA9400) were purchased from Vector Laboratories and secondary antibody goat anti-mouse IgG Alexa Fluor 488 (A11001) was purchased from Molecular Probes. Mouse monoclonal antibody to TSP1, Clone 133 , was developed in our lab [33, 34].

\section{Immunohistochemistry}

Sections of human coronary arteries were obtained from existing paraffin-embedded sections under IRB protocol approval X060928009 to B. Brott. The vessel shown in figure 1a is from the left circumflex artery of a patient undergoing a heart transplant who had been implanted with a Taxus stent within 12 months. Figure $1 \mathrm{~b}$ panels are from a patient who received 4 Cypher stents 12 months prior to autopsy. Results are representative of sections

of coronary arteries stained from 3 separate patients with ISR receiving drug-eluting stents. Antigen retrieval was performed by microwaving sections in $10 \mathrm{~mm}$ citrate buffer, $\mathrm{pH}$ 6.0, for $3 \mathrm{~min}$ at full power and for $7 \mathrm{~min}$ at $40 \%$ power. Sections were incubated in $1 \% \mathrm{H}_{2} \mathrm{O}_{2}$ for $10 \mathrm{~min}$, blocked with $2.5 \%$ ovalbumin for $1 \mathrm{~h}$ at room temperature, and then incubated with primary antibodies overnight at $4^{\circ} \mathrm{C}$. Sections were washed and then incubated with the appropriate biotin-tagged secondary antibodies (1/500 dilution) for $1 \mathrm{~h}$ at room temperature. Following washing, streptavidin/ HRP (ABC kit PK6100) was added to sections for $30 \mathrm{~min}$ at room temperature. Color was developed with the DAB developer (Vector Laboratories SK4100). Some sections were counterstained with hematoxylin. Sections were dehydrated and then mounted with Vectamount media (Vector Labs H5000). Primary antibodies were used at the following concentrations: rabbit anti-phospho Smad 2 
Fig. 1. TSP 1 and active TGF- $\beta$ (pSmad 2) are expressed in arteries with ISR. b Section from a proximal left anterior descending artery implanted with 4 Cypher stents 12 months prior to autopsy. The VSMCs in the mature, fibrous neointima (NI) are positive for both TSP1 and nuclear pSmad 2 . The rectangle denotes the area shown at $20 \times$. Control sections incubated with nonimmune IgG show no staining. $\mathrm{L}=\mathrm{Lu}-$ men.
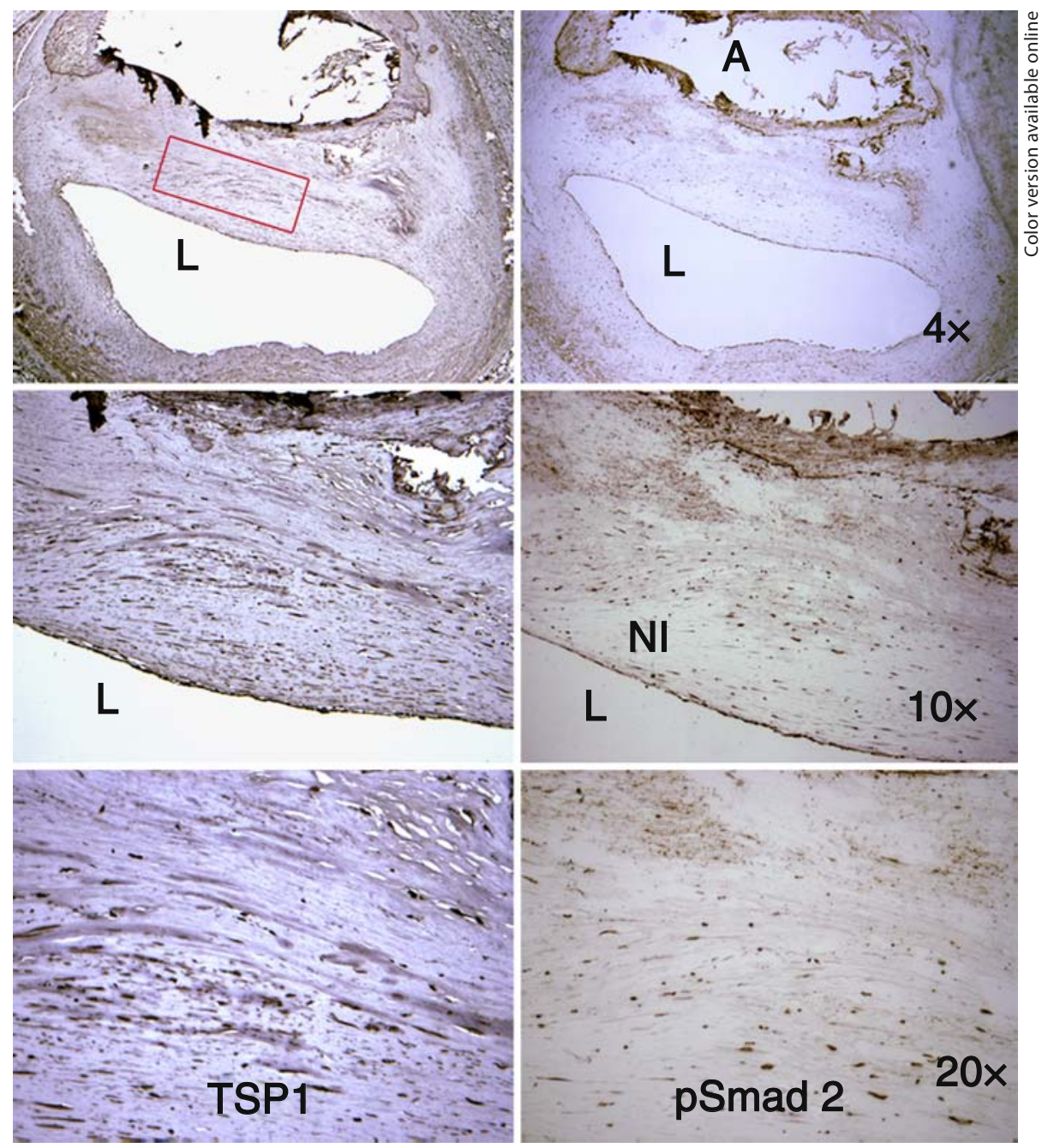

(800 ng/ml); mouse anti-TSP1 $(10 \mu \mathrm{g} / \mathrm{ml}) ;$ rat anti-F4/80 $(10 \mu \mathrm{g} /$ $\mathrm{ml})$; mouse anti-rat CD68 $(10 \mu \mathrm{g} / \mathrm{ml})$; mouse anti-CD11b $(10 \mu \mathrm{g} /$ $\mathrm{ml})$. Nonimmune rabbit, rat and mouse IgG were diluted to the final concentration of the relevant primary antibody.

\section{VSMC Isolation and Culture}

Primary cultures of rat aortic smooth muscle cells (VSMCs) were derived from 10-week-old female Sprague-Dawley rats (Charles River) using the explant method [35]. Cells were routinely cultured in DMEM with 10\% FBS, 2 mmol/l L-glutamine and used between passages 2 and 5 .

\section{Immunocytochemistry}

Cells were grown on glass coverslips in DMEM with 10\% FBS until approximately $60 \%$ confluent. Cells were treated for $24 \mathrm{~h}$ with $0.1 \mathrm{ppm}$ SS ions in dilute acid or dilute acid alone as a control. Cells were fixed in cold $3 \%$ paraformaldehyde for $10 \mathrm{~min}$, washed 3 times in DMEM and permeabilized with $0.1 \%$ Triton X-100 for $3 \mathrm{~min}$. Cells were washed and nonspecific binding sites were blocked with $0.1 \%$ ovalbumin for $30 \mathrm{~min}$ and then incubated with primary antibodies at a final concentration of $4 \mu \mathrm{g} / \mathrm{ml}$ overnight at $4{ }^{\circ} \mathrm{C}$. Cells were washed and incubated with secondary antibody goat anti-mouse IgG Alexa Fluor 488 at a 1/500 dilution and mounted on glass slides using Vectashield. Immunofluorescence was detected using a Nikon Eclipse microscope equipped for epifluorescence at the University of Alabama at Birmingham BERM Center FRET microscopy core facility. All images were obtained at $40 \times$ magnification and were processed identically.

\section{SS Ion Solutions}

To simulate the SS corrosion products, high-purity atomic absorption standards (Acros Organics USA, Morris Plains, N.J., USA) were used. Simulated ion cocktails representing SS corrosion ions were made by addition of $\mathrm{Fe}^{3+}, \mathrm{Ni}^{2+}, \mathrm{Cr}^{3+}, \mathrm{Mn}^{2+}$ and $\mathrm{Mo}^{6+}$ at $66,14,16,2$ and $2 \%$, respectively. Stock solutions at 10 ppm were prepared from $1 \mathrm{mg} / \mathrm{ml}$ stock solutions in $2 \% \mathrm{HNO}_{3}$, except for $\mathrm{Cr}$ which is in a stock of $2 \% \mathrm{HCl}$. Metals were diluted to their final concentration in serum-free DMEM and incubated in a $\mathrm{CO}_{2}$ incubator to equilibrate $\mathrm{pH}$ prior to adding to cells. DMEM with a volume of acid (DMEM/acid) equal to that used for the ion dilution was used as a control for any effects of the acid diluent. 
Treatment of Cells with SS Ions

VSMCs were grown to $50-60 \%$ confluence in 12 -well plates in DMEM with 10\% FBS. Cultures were rinsed in serum-free DMEM and treated with diluted cocktails of metal ions (0.1-1.0 ppm) dissolved in acid. Dilute DMEM/acid controls were run in each assay. The concentrations of metal ions used in these studies did not cause cell death (data not shown). Furthermore, at $0.1 \mathrm{ppm}$, the iron and nickel concentrations are approximately 2 - and 30 -fold, respectively, over levels detected by mass spectrometry normalized per milligram of explanted vascular tissue harvested from autopsy specimens of patients with SS stents [D. Halwani and J. Lemons unpubl. data, UAB Master's thesis]. Cells were treated with metal ions for times indicated. Forty-eight-hour treatments were refreshed at $24 \mathrm{~h}$. Assays were performed in triplicate and extracts pooled in a total volume of $60 \mu \mathrm{l}(20 \mu \mathrm{l} /$ well $)$ of $2 \times$ Laemmli Buffer with protease inhibitors (Sigma-Aldrich P2714) and phosphatase inhibitors (Sigma-Aldrich P2850). Extracts were sonicated for $6 \mathrm{~s}$ to shear DNA and boiled at $100^{\circ} \mathrm{C}$ for $5 \mathrm{~min}$, followed by centrifugation at 10,000 rpm for $2 \mathrm{~min}$. Each assay was repeated a minimum of 3 separate times.

\section{Immunoblotting}

Equal volumes of cell extracts were electrophoretically separated and transferred to nitrocellulose membranes per standard protocols. Multiple films were exposed to ensure linearity of the response. In each experiment, membranes were stripped and reprobed with antibody to $\beta$-tubulin as a loading control for normalization of cell number.

\section{Hydrogen Peroxide Measurement}

The Amplex Red Hydrogen Peroxide/Peroxidase Assay kit (A22188; Invitrogen-Molecular Probes) was used according to manufacturer's instructions. Cell suspensions of 15,000 cells/well in $20 \mu \mathrm{l}$ of serum-free DMEM in the presence or absence of treatments were then added to wells with pre-incubated $\left(37^{\circ} \mathrm{C}, 30 \mathrm{~min}\right)$ Ampex Red-HRP reagent and incubated at $37^{\circ} \mathrm{C}$ with $5 \% \mathrm{CO}_{2}$ for 1-4 h. Hydrogen peroxide produced by cells was measured at 1,2 , 3 and 4 h using a Cytofluor 4000 microplate reader (excitation 530 $\mathrm{nm}$, emission $580 \mathrm{~nm}$; PerSeptive Biosystems). Samples were assayed in triplicate for each condition. Hydrogen peroxide (10 $\mu \mathrm{mol} / \mathrm{l}$ ) was used as a positive control. Wells containing reagents without cells were set as assay background that was subtracted from sample readings.

\section{Statistics}

Results of the hydrogen peroxide assay were analyzed by oneway ANOVA with post hoc Tukey analysis using Sigma Stat 3.1. Results with a p value $<0.05$ are considered significant.

\section{Results}

\section{Localization of TSP1 and Active TGF- $\beta$ in Peri-Stent} Coronary Artery

To determine whether TSP 1 and active TGF- $\beta$ are localized to vascular tissues surrounding stent materials, human autopsy specimens obtained from stented coronary arteries were stained for TSP1 and phosphorylated
Smad 2 (pSmad 2$)$ as an indicator of active TGF- $\beta$ signaling. These studies showed localization of both TSP1 and active TGF- $\beta$ in VSMCs of the restenotic neointima of peri-stent regions (fig. 1a, b). The co-expression of TSP1 and pSmad 2 in VSMCs of the restenotic fibrous neointima suggest that TSP1 might be responsible for locally activating latent TGF- $\beta$ in these lesions. Serial sections stained for macrophage markers (CD68, CD11b) showed that vessels with long-term (approx. 12 months) stent placement had few macrophages in the actual restenotic lesions (data not shown), although macrophages expressing active TGF- $\beta$ were prominent in atheromatous regions, distinct from the neointimal areas of restenotic remodeling.

\section{SS Ions Increase TGF- $\beta$ Activity, TSP1 and}

Extracellular Matrix Production by VSMCs

Rat VSMCs (p3) were treated with SS ions to determine whether metal ions induce increased TGF- $\beta$ activity (pSmad 2; fig. 2a). SS ion treatment stimulated increased Smad 2 phosphorylation in VSMCs. Interestingly, acid diluent used for preparing the SS ions increased total Smad 2, although it had no effect on Smad 2 phosphorylation. It is known that synthetic VSMCs express increased TSP1, a known activator of latent TGF- $\beta$ [36]. Therefore, SS ion-treated VSMC cultures were also examined for TSP1 expression (fig. 2b). The effect of SS ions on extracellular matrix (type I collagen and ED-A FN) production by VSMCs was also examined (fig. 2b, c). Results show that TGF- $\beta$ activity, TSP1 and extracellular matrix proteins are indeed upregulated by SS ion treatment of VSMCs.

\section{SS Ions, TSP1, and TGF- $\beta$ Reduce Expression of \\ VSMC Contractile Protein Desmin}

Loss of VSMC contractile proteins is characteristic of the switch to the synthetic phenotype. Consistent with the induction of increased extracellular matrix and TSP1 by SS ions, SS ions also decrease expression of the VSMC contractile protein, desmin (fig. $2 \mathrm{~d}$ ). Desmin levels are also reduced by treatment with either TSP1 or active TGF- $\beta$ (fig. 2 d). Furthermore, SS ion-treated VSMCs acquire a rhomboid phenotype with loss of the contractile cytoskeletal protein calponin indicative of the synthetic phenotype, as compared to acid control-treated cells which are more spindle shaped and have strong staining for calponin (fig. 3). 


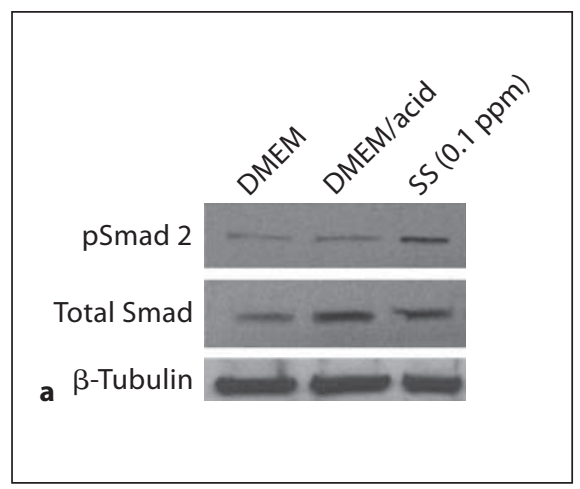

Fig. 2. SS ions stimulate increased TGF- $\beta$ activity, TSP1, extracellular matrix production and reduce desmin expression. VSMCs (p3-4) were cultured in the presence of 0.1-1.0 ppm SS ion cocktail in dilute acid, TGF- $\beta$ (200 pmol/l) or TSP1 (32 $\mathrm{nmol} / \mathrm{l}$ ) for $24 \mathrm{~h}$. Pooled cell lysates from triplicate samples were harvested and proteins were immunoblotted for pSmad 2 and total Smad 2/3 $(n=3)(a)$ or type I collagen $(\mathrm{n}=4)$, TSP1 $(\mathrm{n}=3)(\mathbf{b})$ and ED-A fibronectin $(\mathrm{n}=3)$ or $\alpha$-SMA $(\mathrm{n}=3)(\mathbf{c})$. Blots were stripped and reprobed for $\beta$-tubulin as a loading control. $\mathbf{d}$ Pooled cell lysates of triplicate samples were harvested at $48 \mathrm{~h}$ of treatment and immunoblotted for desmin $(n=4)$. Blots were stripped and reprobed for $\beta$-tubulin.

Fig. 3. SS ion treatment induces the synthetic phenotype in VSMCs. VSMCs were cultured for $24 \mathrm{~h}$ in presence of dilute acid $(\mathbf{a}, \mathbf{c})$ or $0.1 \mathrm{ppm} \mathrm{SS}$ ions $(\mathbf{b}, \mathbf{d})$. Cells were fixed and permeabilized and then stained for calponin (a, b) and vimentin (c, d) by indirect immunofluorescence with an Alexa Fluor 488 secondary antibody. $40 \times$.
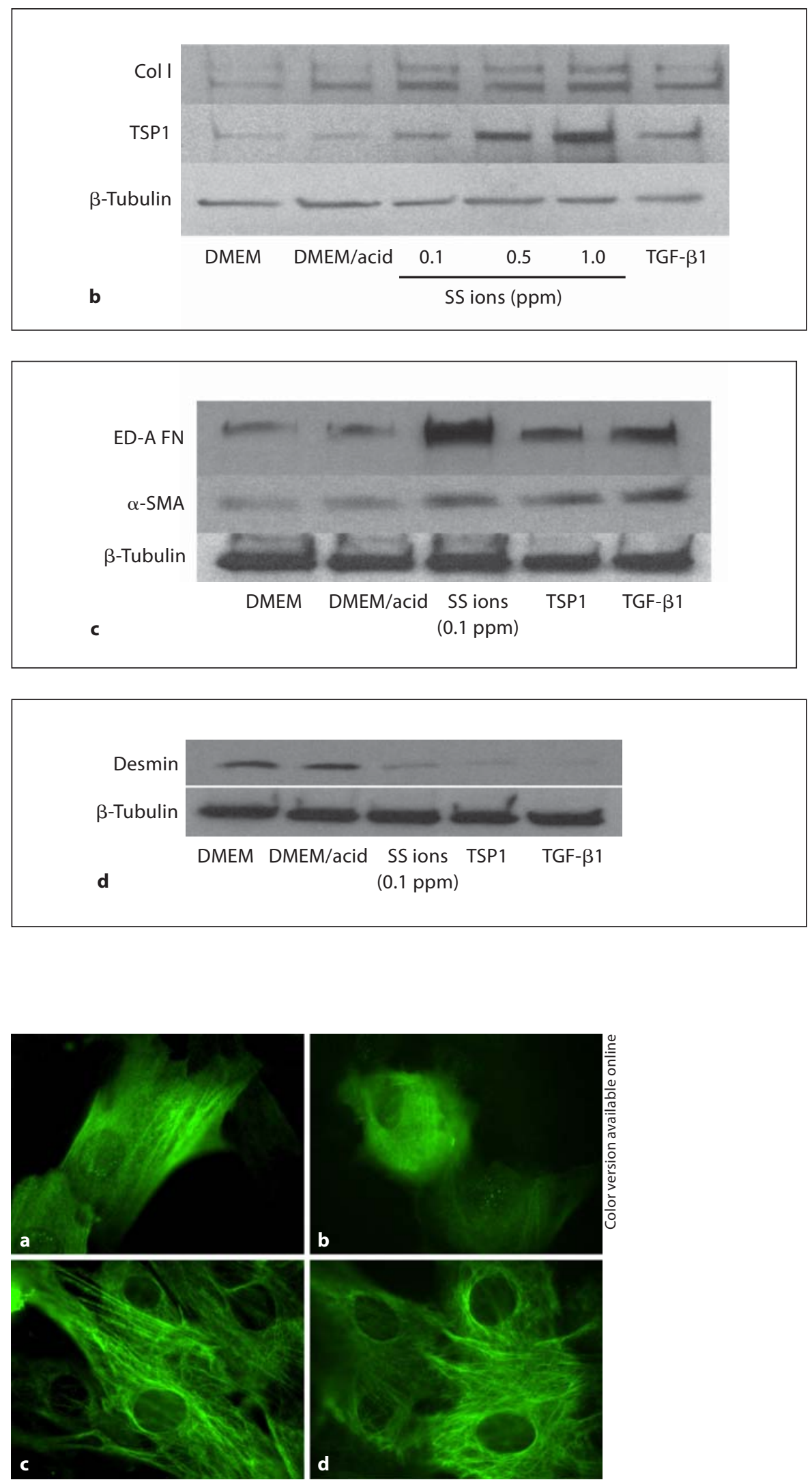

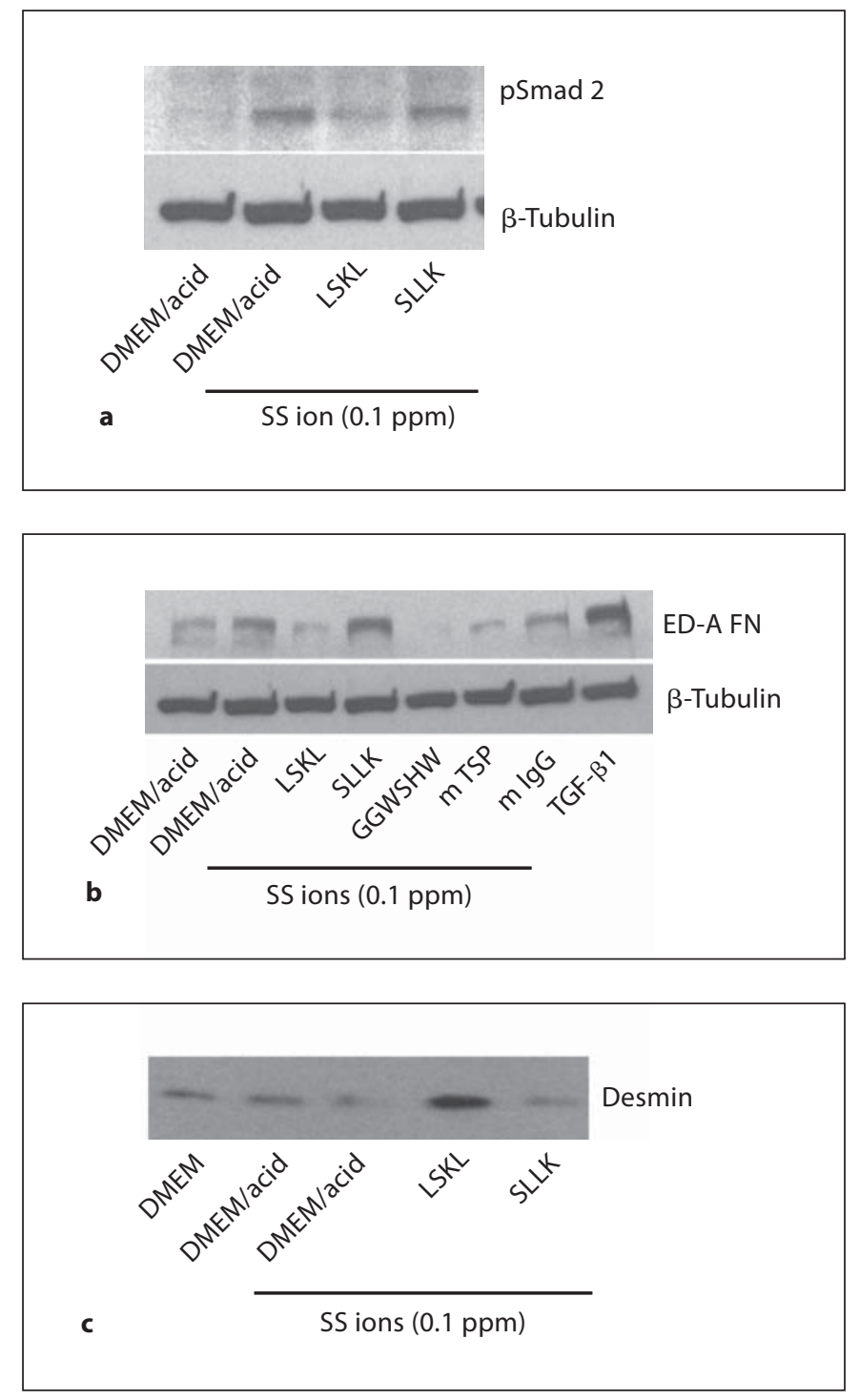

Fig. 4. Blockade of TSP1-dependent TGF- $\beta$ activation reduces TGF- $\beta$ signaling and matrix expression due to SS ions and increases desmin expression. VSMCs (p3) were treated with $0.1 \mathrm{ppm}$ SS ions for $24 \mathrm{~h}$ in the presence or absence of LSKL or SLLK $(1 \mu \mathrm{mol} / \mathrm{l})$, GGWSHW $(20 \mu \mathrm{mol} / \mathrm{l})$ or Mab 133 monoclonal antibody to TSP1 or nonimmune mouse IgG $(25 \mu \mathrm{g} / \mathrm{ml})$. Active TGF$\beta(200 \mathrm{pmol} / \mathrm{l})$ was used as a positive control. Pooled cell lysates from triplicate samples were harvested, separated by SDS-PAGE and proteins analyzed by immunoblotting for phospho-Smad 2 $(\mathrm{n}=3)(\mathbf{a})$ or ED-A fibronectin $(\mathrm{n}=3)(\mathbf{b})$. Membranes were stripped and reprobed for $\beta$-tubulin. c In separate experiments, cells were treated with $0.1 \mathrm{ppm}$ SS ions for $48 \mathrm{~h}$ in the presence of either $1 \mu \mathrm{mol} / \mathrm{l} \mathrm{LSKL}$ or SLLK peptide and cell lysates were harvested and immunoblotted for desmin $(n=3)$.

\section{Blockade of TSP1-Dependent TGF- $\beta$ Activation}

Inhibits SS Ion Stimulation of TGF- $\beta$ Signaling and ED-A Fibronectin Expression and Prevents Desmin Downregulation

Previously, we established that the LSKL peptide acts as a competitive antagonist of TSP1-dependent TGF- $\beta$ activation in vitro and in vivo $[20,22]$. VSMCs treated with SS ions in the presence of $1 \mu \mathrm{M}$ LSKL peptide had reduced TGF- $\beta$ signaling as measured by pSmad 2 and expression of the synthetic/myofibroblastic protein, EDA FN (fig. 4a, b). Control peptide, SLLK, had no effect. Another TSP1 antagonist peptide, GGWSHW, and a monoclonal antibody to TSP1 (Mab133) similarly reduce ED-A FN expression. Furthermore, the action of SS ionstimulated TSP1 in reducing desmin expression is reversed by the LSKL peptide, but not by the control SLLK peptide (fig. 4c).

\section{SS Ions Increase Oxidant Stress}

ISR and metal ions are both known to stimulate increased oxidative stress and a reduction in anti-oxidant enzymes [37]. VSMCs treated with SS ions were measured for the generation of hydrogen peroxide $\left(\mathrm{H}_{2} \mathrm{O}_{2}\right)$. SS ions stimulated increased levels of $\mathrm{H}_{2} \mathrm{O}_{2}$ by $1 \mathrm{~h}$ of treatment, which was sustained during the 4-hour duration of the assay (fig. 5a; data not shown). Catalase, which causes $\mathrm{H}_{2} \mathrm{O}_{2}$ decomposition, blocked SS ion generation of $\mathrm{H}_{2} \mathrm{O}_{2}$ (fig. 5b). In contrast, direct stimulation of VSMCs with either TSP1 or active TGF- $\beta$ failed to stimulate $\mathrm{H}_{2} \mathrm{O}_{2}$ (fig. 5a). Blockade of TSP1-dependent TGF- $\beta$ activation with either inhibitory peptide or a monoclonal antibody had no effect on $\mathrm{H}_{2} \mathrm{O}_{2}$ generation by $\mathrm{SS}$ ions (data not shown), suggesting that the increase in $\mathrm{H}_{2} \mathrm{O}_{2}$ is a direct effect of SS ions and not secondary to either TSP1 or TGF$\beta$ activity stimulation. Interestingly, iron, nickel and, to a greater extent, manganese, appear to be involved in $\mathrm{H}_{2} \mathrm{O}_{2}$ generation (fig. $5 \mathrm{c}$ ).

Since oxidative stress is increased by treatment with SS ions and both TSP 1 and TGF- $\beta$ activity are regulated by ROS, we assessed the role of $\mathrm{H}_{2} \mathrm{O}_{2}$ in these mechanisms. To determine the role of $\mathrm{H}_{2} \mathrm{O}_{2}$ in $\mathrm{SS}$ ion induction of TSP1, TGF- $\beta$ and ED-A FN, VSMCs were treated with catalase which decomposes $\mathrm{H}_{2} \mathrm{O}_{2}$ to water and molecular oxygen. Catalase reduced both TSP1 and ED-A FN expression and also decreased TGF- $\beta$ activity (p-Smad 2) induced by SS ion treatment (fig. 6).

\section{SS Ions Decrease PKG Activity}

NO-dependent PKG activity is a key factor regulating the contractile phenotype of VSMCs and loss of PKG ac- 
Fig. 5. SS ions increase $\mathrm{H}_{2} \mathrm{O}_{2}$ in VSMCs. $\mathrm{H}_{2} \mathrm{O}_{2}$ levels were measured using the Amplex Red Hydrogen Peroxide/Peroxidase assay according to the manufacturer's instructions. a VSMCs (p5) were treated with SS ions (0.1 ppm), TSP1 (32 nmol/l) or active TGF- $\beta$ (200 pmol/l) for $1-4 \mathrm{~h}$. Hydrogen peroxide was measured as fluorometric emission at $580 \mathrm{~nm}$ following excitation at $530 \mathrm{~nm}$ using a Cytofluor 4000 microplate reader. Results are expressed as mean fluorometric units \pm SD of triplicate samples read at $3 \mathrm{~h}$. b In the same experiment, VSMCs (p5) were treated with SS ions in the presence or absence of 100 units of catalase or with catalase alone. Results are expressed as mean fluorometric units $\pm \mathrm{SD}$ of triplicate samples read at 4 h. c VSMCs (p5) were treated with cocktails of SS ions, each lacking one of the metal ion components. Results are expressed as mean fluorometric units $\pm \mathrm{SD}$ of triplicate samples read at $4 \mathrm{~h}$. All experiments were performed in triplicate in at least 2 separate experiments. ${ }^{*} \mathrm{p}<0.027$ vs. SS ion treatment; ${ }^{* *} \mathrm{p}<0.001$ vs. SS ion treatment. n.s. $=$ Not significant.
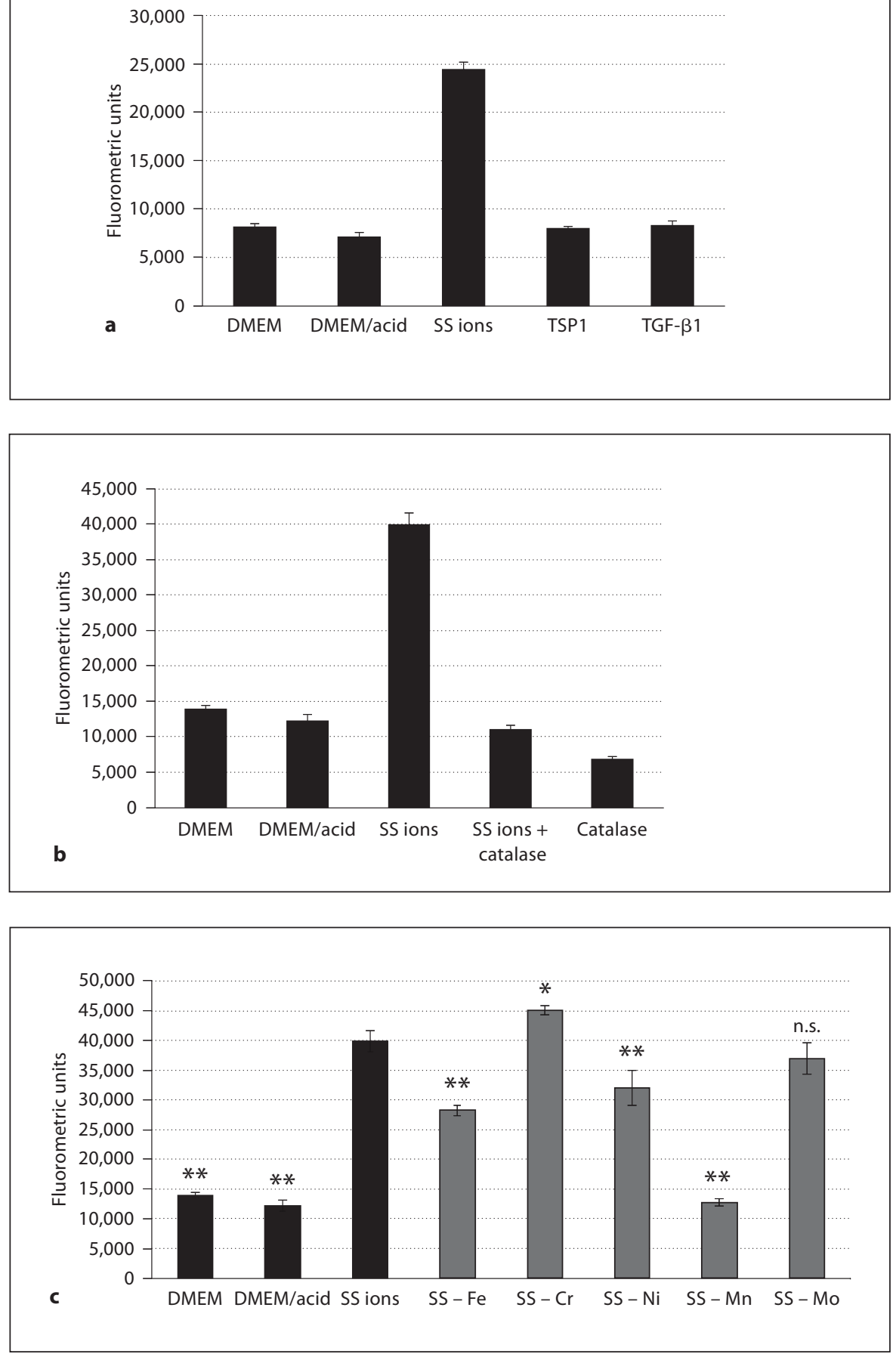

tivity is associated with transition to the synthetic phenotype [38]. Since PKG represses TSP1 expression by VSMCs and also TSP1 transcription by blocking the upregulation of the transcription factor USF2 under highglucose conditions $[25,36]$, we hypothesized that SS ions might attenuate PKG protein or activity leading to an increase in TSP 1 expression and TGF- $\beta$ activation. Since SS ions increase ROS, especially $\mathrm{H}_{2} \mathrm{O}_{2}$, it is possible that SS ions attenuate PKG activity through depletion of bioavailable NO and cGMP. Thus, PKG protein was evalu- 
Fig. 6. Catalase reduces SS ion-induced TSP1 and ED-A FN expression and TGF- $\beta$ activity in VSMCs. VSMCs (p4) were treated with SS ions $(0.1 \mathrm{ppm})$ in the presence or absence of catalase (100 units/ml). Media with dilute acid was used as a control for the SS ion preparation. Cells analyzed for pSmad 2 were treated with both 100 units/ml and 500 units $/ \mathrm{ml}$ catalase. Active TGF- $\beta$ (200 pmol/l) or the PKG activator, 8pCPT-cGMP (1 $\mathrm{mmol} / \mathrm{l})$, were used as positive controls for stimulation of $\mathrm{pSmad}$ 2 and PKG activity, respectively. a Cells harvested after $24 \mathrm{~h}$ of treatment were assayed for TSP1 and ED-A FN ( $n=5)$. b Cells harvested at $6 \mathrm{~h}$ were analyzed for pSmad $2(n=3)$ by immunoblotting of pooled cell lysates from triplicate samples. Blots were reprobed for $\beta$-tubulin.

Fig. 7. SS ions reduce PKG-dependent VASP phosphorylation in VSMCs. VSMCs (p2) were treated with DMEM, dilute acid in DMEM or $0.1 \mathrm{ppm}$ SS ions in dilute acid for 1 or $6 \mathrm{~h}$. Pooled cell lysates of triplicate samples were harvested and immunoblotted with rabbit anti-PKG and rabbit antiphospho-VASP (ser239) antibodies $(\mathrm{n}=3)$. Cells treated with an activator of PKG, 8pCPT-cGMP ( $1 \mathrm{mmol} / \mathrm{l})$, were used as a positive control for VASP phosphorylation. Blots were stripped and reprobed for $\beta$-tubulin as a loading control.

Fig. 8. Catalase blocks SS ion reduction in PKG-dependent VASP phosphorylation in VSMCs. VSMCS (p4) were treated with SS ions $(0.1 \mathrm{ppm})$ for $6 \mathrm{~h}$ in the presence or absence of either 100 units/ml or 500 units/ $\mathrm{ml}$ catalase. Dilute acid is a control for SS ion preparation. $8 \mathrm{pCPT}-\mathrm{cGMP}(1 \mathrm{mmol} / \mathrm{l})$ is a positive control for PKG-dependent VASP phosphorylation. Cell lysates of pooled triplicate samples were analyzed for phospho-VASP (ser239) by immunoblotting $(\mathrm{n}=3)$. Blots were stripped and reprobed for $\beta$-tubulin.
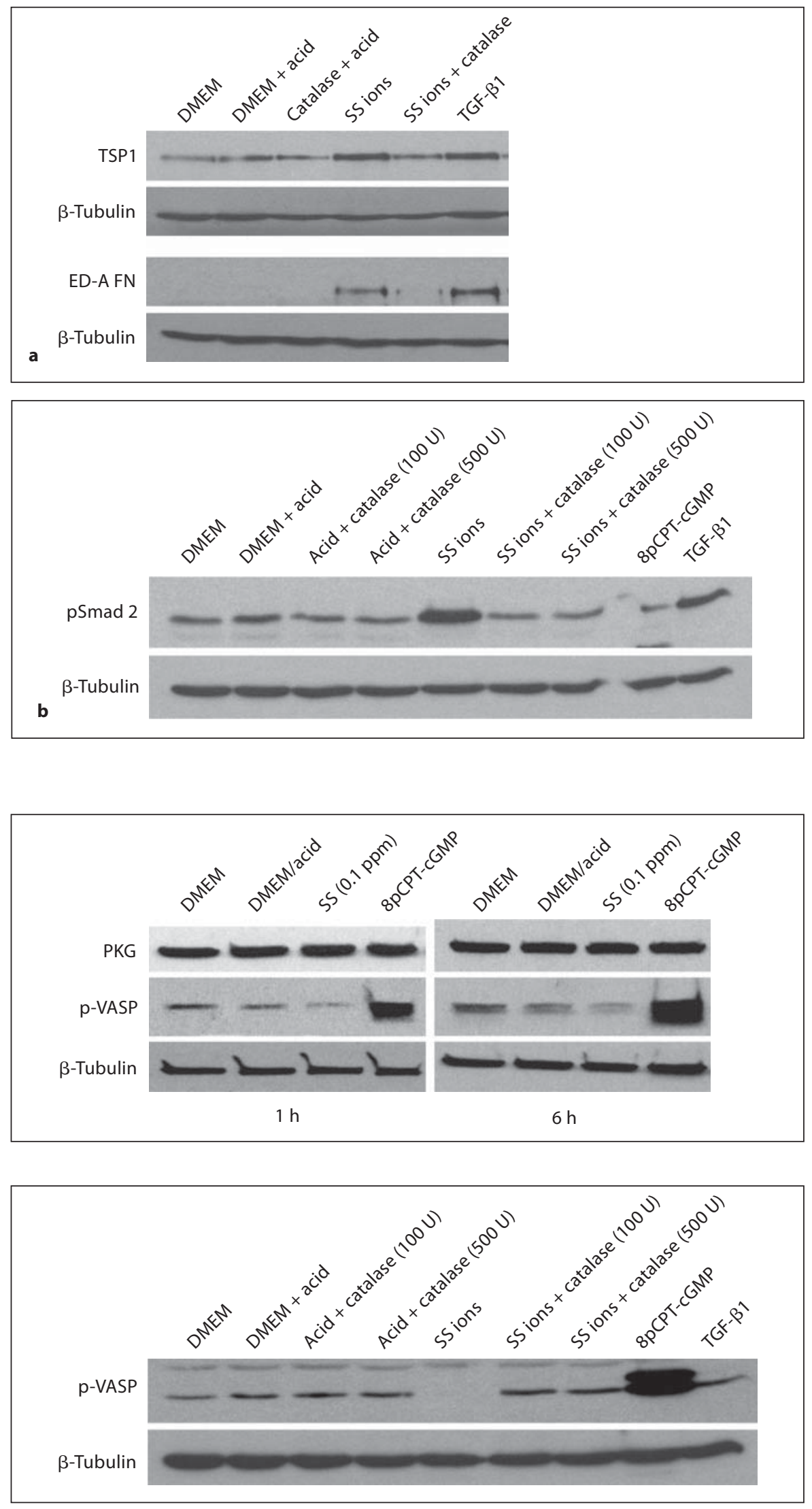
ated following SS ion treatment of VSMCs and PKG activity was determined by immunoblotting for the PKG substrate, phosphorylated VASP (fig. 7). These results show that SS ions do not affect PKG protein expression, but that SS ions do reduce PKG activity as detected by decreased VASP phosphorylation at the PKG-specific site (serine 239). Reduced VASP phosphorylation was detected by 1 and $6 \mathrm{~h}$. Consistent with reduced PKG activity due to lack of NO-generated cGMP under high-ROS conditions, catalase blocked SS ion downregulation of PKG activity (phospho-VASP; fig. 8).

\section{Discussion}

Our current studies show that SS ions stimulate increased TSP1 expression and TSP1-dependent increases in TGF- $\beta$ activity in VSMCs, which stimulates the phenotypic switch to the synthetic phenotype. The SS ions stimulate increased TSP1 expression through a hydrogen peroxide-mediated attenuation of PKG activity to downregulate PKG-mediated repression of TSP1 synthesis. These results provide novel insights into how biodegradation products from stent alloys can influence VSMC responses to drive ISR.

TGF- $\beta$ has complicated effects on the vasculature: on the one hand, it is considered atheroprotective because it stimulates endothelial proliferation through its ALK 1 receptor, and it is thought to enhance plaque stability by increasing extracellular matrix production in the fibrous cap $[39,40]$. TGF- $\beta$ also stimulates VSMC differentiation by increasing expression of $\alpha$-SMA, SMMHC and calponin, and it inhibits SMC proliferation [41]. However, TGF- $\beta$ can also induce PDGF expression to stimulate SMC proliferation and phenotype switching [39]. Different TGF- $\beta$ concentrations in vitro can elicit contradictory responses, making generalizations about TGF- $\beta$ function difficult. However, TGF- $\beta$ expression is rapidly increased following vascular injury in both experimental animals and human specimens, and evidence clearly indicates that TGF- $\beta$ contributes to restenosis [42-44]. Furthermore, activators of TGF- $\beta$, including TSP1, are similarly upregulated at sites of injury in a porcine coronary angioplasty model $[16,24]$. TGF- $\beta$ and its receptors are increased at sites of stenting in a porcine coronary artery model [45]. Increases in TGF- $\beta$ mRNA were observed as early as 5 days following stent deployment and protein was detectable in tissue at 28 days. TGF- $\beta$ was predominantly localized around stent struts, which are known sites of increased VSMC migration [45]. The im- portance of TGF- $\beta$ in vascular remodeling has been established using in vivo models, which either deliver active TGF- $\beta$ or block its action. Expression of constitutively active TGF- $\beta$ induced by gene transfer in uninjured porcine arteries induced collagen and proteoglycan synthesis as well as both intimal and medial hyperplasia [17]. In contrast, neutralizing anti-TGF- $\beta 1$ antibodies suppressed both extracellular matrix accumulation and neointimal hyperplasia in a rat model of carotid balloon injury [46]. Soluble TGF- $\beta$ type II receptor antagonist also decreased negative remodeling and intimal lesions in a rat model of balloon catheterization, but the receptor antagonist had no adverse effect on re-endothelialization [47]. Not surprisingly, therapeutic approaches aimed at blocking the fibroproliferative effects of TGF- $\beta$ on restenosis and ISR have been tested. In pigs undergoing coronary stent implantation, tranilast treatment attenuated TGF- $\beta$ and TGF- $\beta$ receptor expression, reduced leukocyte accumulation and significantly reduced neointimal hyperplasia [45]. Others have used pioglitazone to treat ISR in rabbits through reducing TGF- $\beta$ and MCP-1 [48]. Our current studies suggest that regulating TGF- $\beta$ activity through attenuation of TSP1-dependent TGF- $\beta$ activation may represent a new therapeutic approach to treating restenosis.

TSP1 is a multifunctional matricellular protein that is upregulated after arterial injury and has been implicated in the process of restenosis $[23,24]$. In addition to activating TGF- $\beta$, TSP 1 also stimulates endothelial cell apoptosis and acts as a mitogen and chemoattractant for VSMCs [49-51]. Release from platelet $\alpha$-granules and activated macrophages are potential sources of TSP1 in early vascular injury and stent placement. However, both PDGF and TGF- $\beta$ induce TSP1 expression by VSMCs [52]. There are multiple lines of evidence to suggest that TSP1 is important in restenosis after balloon angioplasty and stent placement. TSP1 expression as measured by gene array and by immunohistochemistry is markedly enhanced in atherectomy-isolated neointima of arteries from patients with ISR [53]. Similarly, VSMCs obtained from coronary atherectomy specimens of patients with ISR had 1.7-fold increases in TSP1 as compared to normal medial VSMCs [54]. Our staining of TSP1 in the neointima of arteries from peri-stent regions also indicates TSP1 expression by neointimal VSMC-like cells, although others failed to observe TSP1 immunostaining in restenotic lesions following balloon angioplasty [55]. Furthermore, an in vitro study evaluating differential gene expression of circulating peripheral blood cells after $90 \mathrm{~min}$ exposure to SS stents found that TSP1 was the most markedly $(>1,500$ - 
fold) upregulated gene [23]. Antibody blockade of TSP1 accelerates re-endothelialization and reduces neointimal formation, potentially acting by inhibiting endothelial cell apoptosis and VSMC proliferation [56]. The role of TSP1 as an activator of latent TGF- $\beta$ in restenosis has not been previously investigated. Our data strongly suggest that TSP1-dependent TGF- $\beta$ activation plays a role in restenotic vascular remodeling due to stent alloy corrosion.

There are also contrasting reports which suggest alternate roles for TSP1 in vascular responses to injury. Neointima formation following carotid artery ligation is reduced in TSP1 null mice, with decreased $\alpha$-SMA-positive cells, but increased collagen and osteopontin deposition [57]. Others observed no difference in vascular response to wire-induced injury between wild-type and TSP1 null mice, but more thrombus formation [58]. Because TSP1 has multiple functions apart from regulation of TGF- $\beta$ activation, including regulating MMP activity and NO signaling, these null phenotypes might reflect the absence of multiple, sometimes contradictory functions. It is also likely that cellular responses to TSP1 vary with the agent inducing vascular injury, the oxidative milieu and any underlying disease such as hypertension, diabetes and atherosclerosis.

Factors regulating VSMC phenotype switching are not completely understood. PKG is a major regulator of the contractile phenotype in adult smooth muscle cells [38]. Loss of PKG results in downregulation of contractile elements and increased expression of extracellular matrix proteins such as TSP1 and osteopontin [38]. Anderson et al. [59] showed that arterial PKG expression is decreased following balloon angioplasty and that loss of PKG coincides with increased osteopontin expression. Furthermore, expression of constitutively active PKG reduces neointima formation in a model of ISR [60]. PKG activity is dependent on NO-stimulated cGMP generation, which can be decreased in the presence of elevated ROS. PKG protein itself can also be downregulated by high levels of cAMP, cGMP or inflammatory mediators [38]. Previously, we showed that culture of mesangial cells or VSMCs with $30 \mathrm{~mm}$ glucose, which reduces bioavailable NO, downregulates PKG activity with increased TSP1 expression and TGF- $\beta$ activity [61; S. Wang, T. Lincoln and J. Murphy-Ullrich, manuscript in preparation]. Our data now provide a link between metal ion-induced oxidative stress, PKG signaling and induction of the TSP1-TGF- $\beta$ axis, suggesting that PKG regulation of TSP1 expression and the consequent TGF- $\beta$ activation are involved in VSMC phenotype regulation by SS ions.
Interestingly, PKG activity has also been shown to inhibit TGF- $\beta$ signaling in VSMCs and endothelial cells through inhibition of pSmad nuclear translocation, but not by inhibition of Smad phosphorylation $[62,63]$.

$\mathrm{NO}$ deficiency is associated with restenosis. Stenting also increases ROS, including hydrogen peroxide $\left(\mathrm{H}_{2} \mathrm{O}_{2}\right)$, superoxide anion $\left(\mathrm{O}_{2} \cdot^{-}\right)$and hydroxyl radical $\left(\mathrm{OH}^{\cdot}\right)$ [15] . Antioxidant enzymes are decreased in rabbit tissues surrounding both titanium and SS implants [64]. High $\mathrm{H}_{2} \mathrm{O}_{2}$ and decreased catalase activity in response to implant debris can activate $\mathrm{NF \kappa B}$ and initiate cytokine production [13]. Furthermore, macrophage attachment and $\mathrm{H}_{2} \mathrm{O}_{2}$ generation on SS surfaces was increased as compared to macrophages attached to diamond-like carbon filmcoated steel surfaces, indicating that SS surfaces elicit ROS [65]. Inhibition of ROS signaling by various antioxidant approaches has been tested as a therapeutic approach to ISR. NO donors or stimulation of endogenous NO via $L$-arginine limits ISR in rabbit and rat aortas through increasing NO, cGMP and by inhibiting VSMC proliferation [66]. These data underscore the importance of ROS in mediating ISR.

Oxidation of specific amino acids on LAP leads to a conformational change in the latent complex, resulting in release of active TGF- $\beta$ [67]. Furthermore, NAD(P)H oxidase 4 (NOX4), an enzyme which generates superoxide, mediates TGF- $\beta 1$ conversion of fibroblasts to myofibroblasts [68]. The free radical scavenger NO inhibits TSP1 synthesis [61]. Conversely, TSP1 binding to its receptors CD47 or CD36 inhibits NO signaling by preventing cGMP accumulation [69]. This suggests that TSP1 is elevated when free radicals are high and NO is low, and that TSP1 itself might contribute to its auto-induction in a feed-forward loop. Furthermore, it is well established that $\mathrm{H}_{2} \mathrm{O}_{2}$ and oxidants generated by high glucose increase TGF- $\beta$ expression and activity and that NO downregulates TSP1 expression in mesangial cells [70,71]. Our data are supportive of a role for $\mathrm{H}_{2} \mathrm{O}_{2}$ in regulating PKG activity, TSP1 expression and TGF- $\beta$ activity in VSMCs due to SS ions. Interestingly, MnTBAP, a mimetic of superoxide dismutase which converts superoxide anion to $\mathrm{H}_{2} \mathrm{O}_{2}$, actually increased ED-A FN and $\alpha$-SMA production by mesenchymal stem cells in the presence or absence of SS ions (data not shown). The $\mathrm{H}_{2} \mathrm{O}_{2}$ generation assays demonstrated a requirement for manganese, iron and nickel ions. Of these ions, manganese alone was sufficient to generate $\mathrm{H}_{2} \mathrm{O}_{2}$ by VSMCs (data not shown), which is consistent with reports that manganese catalyzes $\mathrm{H}_{2} \mathrm{O}_{2}$ from dioxygen [72]. Furthermore, manganese chloride can induce the release of $\mathrm{H}_{2} \mathrm{O}_{2}$ from microglial cells [14]. 
In summary, these studies identify a molecular pathway involved in vascular smooth muscle cell-driven restenotic responses activated by the metal ions. These studies support the idea that corrosion of endovascular stent metals contributes to the problem of ISR through the release of metal ions to the vascular wall. These data suggest that methods to reduce stent metal corrosion or, alternately, to block the metal ion-triggered TSP1-TGF- $\beta$ activation pathway might represent novel approaches to treat ISR.

\section{Acknowledgements}

The authors would like to thank Ms. Patricia Lott for assistance with histologic processing of tissue specimens and $\mathrm{Mr}$. Shawn Williams at the BERM/University of Alabama at Birmingham FRET Microscopy Core Facility.

This work was supported by NIH grants HL079644 and DK078038 to J.E.M.-U., an NIH Research Facilities Improvement Program Grant C06 RR 15490, grants HL080017 and HL044195 to Y.-F.C. M.T.R. was supported by an NIH predoctoral dental scientist fellowship F30DE018259. Support for histological tissue processing was from NIBIB-BRP grant EB001715 (J.L.).

\section{References}

1 Scott NA: Restenosis following implantation of bare metal coronary stents: Pathophysiology and pathways involved in the vascular response to injury. Adv Drug Deliv Rev 2006; 58:358-376

2 Santin M, Colombo P, Bruschi G: Interfacial biology of in-stent restenosis. Expert Rev Med Devices 2005;2:429-443.

3 Celik T, Iyisoy A, Jata B, Yuksel CU, Isik E: Stent fracture: a new villain of the village. Int J Cardiol 2008, E-pub ahead of print.

-4 Kim JS, Lee SY, Lee JM, Yoon YW, Ahn CM, Kim MH, Min PK, Ko YG, Hong BK, Choi D, Kwon HM, Jang Y, Shim WH: Significant association of coronary stent fracture with instent restenosis in sirolimus-eluting stents. Coron Artery Dis 2009;20:59-63.

$\checkmark 5$ Rits J, van Herwaarden JA, Jahrome AK, Krievins D, Moll FL: The incidence of arterial stent fractures with exclusion of coronary, aortic, and non-arterial settings. Eur J Vasc Endovasc Surg 2008;36:339-345.

6 Lee SH, Kim JG, Choi HW, Lee KR: Microtensile strain on the corrosion performance of diamond-like carbon coating. J Biomed Mater Res A 2008;85:808-814.

7 Roy RK, Lee KR: Biomedical applications of diamond-like carbon coatings: a review. J Biomed Mater Res B Appl Biomater 2007;83: $72-84$.

$\$ 8$ Uo M, Watari F, Yokoyama A, Matsuno H, Kawasaki T: Tissue reaction around metal implants observed by x-ray scanning analytical microscopy. Biomaterials 2001;22:677-685.

-9 Shih CC, Lin SJ, Chung KH, Chen YL, Su YY: Increased corrosion resistance of stent materials by converting current surface film of polycrystalline oxide into amorphous oxide. J Biomed Mater Res 2000;52:323-332.

$\checkmark 10$ Shih CC, Shih CM, Chou KY, Lin SJ, Su YY: Stability of passivated 3161 stainless steel oxide films for cardiovascular stents. J Biomed Mater Res A 2007;80:861-873.

-11 Koster R, Vieluf D, Kiehn M, Sommerauer M, Kahler J, Baldus S, Meinertz T, Hamm CW: Nickel and molybdenum contact allergies in patients with coronary in-stent restenosis. Lancet 2000;356:1895-1897.
12 Santin M, Mikhalovska L, Lloyd AW, Mikhalovsky S, Sigfrid L, Denyer SP, Field S, Teer D: In vitro host response assessment of biomaterials for cardiovascular stent manufacture. J Mater Sci Mater Med 2004;15:473477.

13 Tucci M BR, Benqhuzzi H, Hughes J: Levels of hydrogen peroxide in tissues adjacent to failing implantable devices may play an active role in cytokine production. Biomed Sci Instrum 2000;36:215-220.

14 Zhang P, Hatter A, Liu B: Manganese chloride stimulates rat microglia to release hydrogen peroxide. Toxicol Lett 2007;173:88100.

15 Patel RP, Moellering D, Murphy-Ullrich J, Jo H, Beckman JS, Darley-Usmar VM: Cell signaling by reactive nitrogen and oxygen species in atherosclerosis. Free Radic Biol Med 2000;28:1780-1794.

16 Chamberlain J: Transforming growth factor- $\beta$ : a promising target for anti-stenosis therapy. Cardiovasc Drug Rev 2001;19:329344.

17 Nabel EG, Shum L, Pompili VJ, Yang ZY, San H, Shu HB, Liptay S, Gold L, Gordon D, Derynck R, et al: Direct transfer of transforming growth factor $\beta 1$ gene into arteries stimulates fibrocellular hyperplasia. Proc Natl Acad Sci USA 1993;90:10759-10763.

18 Bornstein P, Agah A, Kyriakides TR: The role of thrombospondins 1 and 2 in the regulation of cell-matrix interactions, collagen fibril formation, and the response to injury. Int J Biochem Cell Biol 2004;36:1115-1125.

19 Murphy-Ullrich JE, Poczatek M: Activation of latent TGF- $\beta$ by thrombospondin-1: mechanisms and physiology. Cytokine Growth Factor Rev 2000;11:59-69.

20 Ribeiro SM, Poczatek M, Schultz-Cherry S, Villain M, Murphy-Ullrich JE: The activation sequence of thrombospondin-1 interacts with the latency-associated peptide to regulate activation of latent transforming growth factor- $\beta$. J Biol Chem 1999;274: 13586-13593.
21 Murphy-Ullrich JE: Thrombospondin-dependent activation of latent TGF- $\beta$ in fibrosis and disease; in Jakowlew SB (ed): Transforming growth factor- $\beta$ in cancer therapy. Totowa, Humana Press, 2008, vol I, pp 549567.

22 Belmadani S, Bernal J, Wei CC, Pallero MA, Dell'italia L, Murphy-Ullrich JE, Berecek $\mathrm{KH}$ : A thrombospondin-1 antagonist of transforming growth factor- $\beta$ activation blocks cardiomyopathy in rats with diabetes and elevated angiotensin II. Am J Pathol 2007;171:777-789.

23 Hoffmann J, Simon P, Zimmermann AK, Lemancyk M, Walter T, Beyer M, Hoffmeister HM, Ziemer G, Wendel HP: Thrombospondin 1 as possible key factor in the hemocompatibility of endocoronary prostheses. Biomaterials 2005;26:5240-5250.

24 Chamberlain J, Gunn J, Francis SE, Holt CM, Arnold ND, Cumberland DC, Ferguson MW, Crossman DC: TGF $\beta$ is active, and correlates with activators of tgfbeta, following porcine coronary angioplasty. Cardiovasc Res 2001;50:125-136.

25 Wang S, Skorczewski J, Feng X, Mei L, Murphy-Ullrich JE: Glucose up-regulates thrombospondin 1 gene transcription and transforming growth factor- $\beta$ activity through antagonism of CGMP-dependent protein kinase repression via upstream stimulatory factor 2. J Biol Chem 2004;279:3431134322.

26 Skowasch D, Jabs A, Andrie R, Dinkelbach S, Luderitz B, Bauriedel G: Presence of bonemarrow- and neural-crest-derived cells in intimal hyperplasia at the time of clinical instent restenosis. Cardiovasc Res 2003;60: 684-691.

27 Owens GK: Regulation of differentiation of vascular smooth muscle cells. Physiol Rev 1995;75:487-517.

28 Glukhova MA, Frid MG, Shekhonin BV, Vasilevskaya TD, Grunwald J, Saginati M, Koteliansky VE: Expression of extra domain a fibronectin sequence in vascular smooth muscle cells is phenotype dependent. J Cell Biol 1989;109:357-366. 
-29 Lincoln TM, Dey NB, Boerth NJ, Cornwell TL, Soff GA: Nitric oxide-cyclic GMP pathway regulates vascular smooth muscle cell phenotypic modulation: implications in vascular diseases. Acta Physiol Scand 1998;164: 507-515.

- 30 Anderson PG, Boerth NJ, Liu M, McNamara DB, Cornwell TL, Lincoln TM: Cyclic GMPdependent protein kinase expression in coronary arterial smooth muscle in response to balloon catheter injury. Arterioscler Thromb Vasc Biol 2000;20:2192-2197.

- 31 Emura M OA, Horino M, Arndt W, Kamino K, Hirohashi S: Development of myofibroblasts from human bone marrow mesenchymal stem cells cocultured with human colon carcinoma cells and TGF $\beta$ 1. In Vitro Cell Dev Biol Anim 2000;36:77-80.

32 Murphy-Ullrich JE, Schultz-Cherry S, Hook $\mathrm{M}$ : Transforming growth factor- $\beta$ complexes with thrombospondin. Mol Biol Cell 1992; 3:181-188.

- 33 Annis DS, Murphy-Ullrich JE, Mosher DF: Function-blocking antithrombospondin-1 monoclonal antibodies. J Thromb Haemost 2006;4:459-468.

-34 Schultz-Cherry S, Murphy-Ullrich JE: Thrombospondin causes activation of latent transforming growth factor- $\beta$ secreted by endothelial cells by a novel mechanism. J Cell Biol 1993;122:923-932.

- 35 Xing D, Feng W, Miller AP, Weathington NM, Chen YF, Novak L, Blalock JE, Oparil S: Estrogen modulates TNF- $\alpha$-induced inflammatory responses in rat aortic smooth muscle cells through estrogen receptor-beta activation. Am J Physiol Heart Circ Physiol 2007;292:H2607-H2612.

- 36 Dey NB, Boerth NJ, Murphy-Ullrich JE, Chang PL, Prince CW, Lincoln TM: Cyclic GMP-dependent protein kinase inhibits osteopontin and thrombospondin production in rat aortic smooth muscle cells. Circ Res 1998;82:139-146.

37 Misra P, Reddy PC, Shukla D, Caldito GC, Yerra L, Aw TY: In-stent stenosis: potential role of increased oxidative stress and glutathione-linked detoxification mechanisms. Angiology 2008;59:469-474.

- 38 Lincoln TM, Dey N, Sellak H: Invited review: cGMP-dependent protein kinase signaling mechanisms in smooth muscle: from the regulation of tone to gene expression. J Appl Physiol 2001;91:1421-1430.

- 39 Bobik A: Transforming growth factor- $\beta$ and vascular disorders. Arterioscler Thromb Vasc Biol 2006;26:1712-1720.

40 Grainger DJ: Transforming growth factor $\beta$ and atherosclerosis: so far, so good for the protective cytokine hypothesis. Arterioscler Thromb Vasc Biol 2004;24:399-404.

- 41 Owens GK, Geisterfer AA, Yang YW, Komoriya A: Transforming growth factor- $\beta$ induced growth inhibition and cellular hypertrophy in cultured vascular smooth muscle cells. J Cell Biol 1988;107:771-780.
42 Majesky MW, Lindner V, Twardzik DR, Schwartz SM, Reidy MA: Production of transforming growth factor $\beta 1$ during repair of arterial injury. J Clin Invest 1991;88: 904-910.

-43 Nikol S, Isner JM, Pickering JG, Kearney M, Leclerc G, Weir L: Expression of transforming growth factor- $\beta 1$ is increased in human vascular restenosis lesions. J Clin Invest 1992;90:1582-1592.

44 Rasmussen LM, Wolf YG, Ruoslahti E: Vascular smooth muscle cells from injured rat aortas display elevated matrix production associated with transforming growth factor$\beta$ activity. Am J Pathol 1995;147:1041-1048.

45 Ward MR, Agrotis A, Kanellakis P, Hall J, Jennings G, Bobik A: Tranilast prevents activation of transforming growth factor-beta system, leukocyte accumulation, and neointimal growth in porcine coronary arteries after stenting. Arterioscler Thromb Vasc Biol 2002;22:940-948.

46 Wolf YG, Rasmussen LM, Ruoslahti E: Antibodies against transforming growth factor$\beta 1$ suppress intimal hyperplasia in a rat model. J Clin Invest 1994;93:1172-1178.

47 Smith JD, Bryant SR, Couper LL, Vary CP, Gotwals PJ, Koteliansky VE, Lindner V: Soluble transforming growth factor- $\beta$ type II receptor inhibits negative remodeling, fibroblast transdifferentiation, and intimal lesion formation but not endothelial growth. Circ Res 1999;84:1212-1222.

48 Joner M, Farb A, Cheng Q, Finn AV, Acampado E, Burke AP, Skorija K, Creighton W, Kolodgie FD, Gold HK, Virmani R: Pioglitazone inhibits in-stent restenosis in atherosclerotic rabbits by targeting transforming growth factor- $\beta$ and MCP-1. Arterioscler Thromb Vasc Biol 2007;27:182-189.

49 Majack RA, Goodman LV, Dixit VM: Cell surface thrombospondin is functionally essential for vascular smooth muscle cell proliferation. J Cell Biol 1988;106:415-422.

50 Yabkowitz R, Mansfield PJ, Ryan US, Suchard SJ: Thrombospondin mediates migration and potentiates platelet-derived growth factor-dependent migration of calf pulmonary artery smooth muscle cells. J Cell Physiol 1993;157:24-32.

51 Good DJ, Polverini PJ, Rastinejad F, Le Beau MM, Lemons RS, Frazier WA, Bouck NP: A tumor suppressor-dependent inhibitor of angiogenesis is immunologically and functionally indistinguishable from a fragment of thrombospondin. Proc Natl Acad Sci USA 1990;87:6624-6628.

52 Majack RA, Cook SC, Bornstein P: Plateletderived growth factor and heparin-like glycosaminoglycans regulate thrombospondin synthesis and deposition in the matrix by smooth muscle cells. J Cell Biol 1985;101: 1059-1070.
53 Zohlnhofer D, Klein CA, Richter T, Brandl R, Murr A, Nuhrenberg T, Schomig A, Baeuerle PA, Neumann FJ: Gene expression profiling of human stent-induced neointima by cDNA array analysis of microscopic specimens retrieved by helix cutter atherectomy: Detection of fk506-binding protein 12 upregulation. Circulation 2001;103:1396-1402.

-54 Zhang QJ, Goddard M, Shanahan C, Shapiro L, Bennett M: Differential gene expression in vascular smooth muscle cells in primary atherosclerosis and in stent stenosis in humans. Arterioscler Thromb Vasc Biol 2002;22: 2030-2036.

55 Riessen R, Kearney M, Lawler J, Isner JM: Immunolocalization of thrombospondin-1 in human atherosclerotic and restenotic arteries. Am Heart J 1998;135:357-364.

56 Chen D, Asahara T, Krasinski K, Witzenbichler B, Yang J, Magner M, Kearney M, Frazier WA, Isner JM, Andres V: Antibody blockade of thrombospondin accelerates reendothelialization and reduces neointima formation in balloon-injured rat carotid artery. Circulation 1999;100:849-854.

57 Moura R, Tjwa M, Vandervoort P, Cludts K, Hoylaerts MF: Thrombospondin-1 activates medial smooth muscle cells and triggers neointima formation upon mouse carotid artery ligation. Arterioscler Thromb Vasc Biol 2007;27:2163-2169.

58 Budhani F, Leonard KA, Bergdahl A, Gao J, Lawler J, Davis EC: Vascular response to intra-arterial injury in the thrombospondin-1 null mouse. J Mol Cell Cardiol 2007;43:210214.

-59 Anderson PG, Boerth NJ, Liu M, McNamara DB, Cornwell TL, Lincoln TM: Cyclic GMPdependent protein kinase expression in coronary arterial smooth muscle in response to balloon catheter injury. Arterioscler Thromb Vasc Biol 2000;20:2192-2197.

60 Sinnaeve P, Chiche JD, Gillijns H, Van Pelt N, Wirthlin D, Van De Werf F, Collen D, Bloch KD, Janssens S: Overexpression of a constitutively active protein kinase $\mathrm{G}$ mutant reduces neointima formation and instent restenosis. Circulation 2002;105:29112916.

61 Wang S, Shiva S, Poczatek MH, Darley-Usmar V, Murphy-Ullrich JE: Nitric oxide and cGMP-dependent protein kinase regulation of glucose-mediated thrombospondin 1-dependent transforming growth factor- $\beta$ activation in mesangial cells. J Biol Chem 2002; 277:9880-9888.

62 Saura M, Zaragoza C, Herranz B, Griera M, Diez-Marques L, Rodriguez-Puyol D, Rodriguez-Puyol M: Nitric oxide regulates transforming growth factor- $\beta$ signaling in endothelial cells. Circ Res 2005;97:1115-1123.

63 Li P, Oparil S, Novak L, Cao X, Shi W, Lucas J, Chen YF: ANP signaling inhibits TGF- $\beta$ induced Smad 2 and Smad 3 nuclear translocation and extracellular matrix expression in rat pulmonary arterial smooth muscle cells. J Appl Physiol 2007;102:390-398. 
-64 Ozmen I, Naziroglu M, Okutan R: Comparative study of antioxidant enzymes in tissues surrounding implant in rabbits. Cell Biochem Funct 2006;24:275-281.

-65 Ball M, O’Brien A, Dolan F, Abbas G, McLaughlin JA: Macrophage responses to vascular stent coatings. J Biomed Mater Res A 2004;70:380-390.

-66 Do YS, Kao EY, Ganaha F, Minamiguchi H, Sugimoto K, Lee J, Elkins CJ, Amabile PG, Kuo MD, Wang DS, Waugh JM, Dake MD: In-stent restenosis limitation with stentbased controlled-release nitric oxide: Initial results in rabbits. Radiology 2004;230:377382 .
67 Barcellos-Hoff MH, Dix TA: Redox-mediated activation of latent transforming growth factor- $\beta$ 1. Mol Endocrinol 1996;10:10771083.

68 Cucoranu I, Clempus R, Dikalova A, Phelan PJ, Ariyan S, Dikalov S, Sorescu D: NAD $(\mathrm{P}) \mathrm{H}$ oxidase 4 mediates transforming growth factor- $\beta 1$-induced differentiation of cardiac fibroblasts into myofibroblasts. Circ Res 2005;97:900-907.

69 Isenberg JS, Wink DA, Roberts DD: Thrombospondin-1 antagonizes nitric oxide-stimulated vascular smooth muscle cell responses. Cardiovasc Res 2006;71:785-793.
70 Craven PA, Studer RK, Felder J, Phillips S, DeRubertis FR: Nitric oxide inhibition of transforming growth factor- $\beta$ and collagen synthesis in mesangial cells. Diabetes 1997; 46:671-681.

71 Wang S, Shiva S, Poczatek MH, Darley-Usmar V, Murphy-Ullrich JE: Nitric oxide and cGMP-dependent protein kinase regulation of glucose-mediated thrombospondin 1-dependent transforming growth factor- $\beta$ activation in mesangial cells. J Biol Chem 2002; 277:9880-9888.

72 Sheriff TS, Cope S, Ekwegh M: Calmagite dye oxidation using in situ generated hydrogen peroxide catalysed by manganese(II) ions. Dalton Trans 2007:5119-5122. 